threat of suit with a judicial pronouncement of his patent's validity, competitors are not likely to risk a court battle. Only the most determined infringers will contest a patent once pronounced valid by a court. ${ }^{30}$ The others must pay tribute to the patentee for the legal privilege of using his "invention." if they cannot afford the license fees, they will have to stop using their "infringing" device. In either event, the benefits of competition are unjustifiably denied the public. ${ }^{38}$

To remove spurious patents as a block to competition, district courts should adopt flexible modes of procedure. Uninfringed patents should not be pronounced valid since that finding may bolster an unearned monopoly. Conversely, courts should not postpone decision when they can wipe out invalid grants. If district courts persist in needlessly finding patents valid and in ignoring evidence of invalidity, courts of appeal should correct them and point the way. ${ }^{39}$

36. Of course all existing patents threaten competitors to some degree. Sce Addressograph-Multigraph Corp. v. Cooper, 156 F.2d 483, 485 (2d Cir. 1946); Brcsnick v. U.S. Vitamin Corp., 139 F.2d 239, 242 (2d Cir. 1943; Cover v. Schwartz, 133 F.2d 541, 545 (2d Cir. 1942) (concurring opinion). This, however, is a price necessarily paid, under the present system, for encouraging inverition. An unnecessary declaration of validity, on the other hand, may pay the price with no corresponding return. See Harries v. Air King Products Co., 183 F.2d 158, 163 (2d Cir. 1950); Wabash Corp. v. Ross Electric Corp., 187 F.2d 577, 593 (partially concurring and partially dissenting opinion).

37. An important incident of patent ownership is the right to grant licenses which permit others to make, use, or sell the patented invention. A customary payment for such privilege is a license fee, i.e. a lump-sum payment made at the time of the agreement. Bennett, The American Patent Systenr 153-181 (1943).

As to the way in which threat of suit may compel competitors to abandon use of $a$ device or enter into license agreements, see Aero Spark Plug Co. v. B.G. Corp., 130 F.2.1 290, 292 (2d Cir. 1942) (concurring opinion); Hamilton Patents ANd FineE ENtellprise 111 (TNEC Monograph 31, 1941); Bennett, The Adrerican Patent Systesr 106 (1943).

38. For the harmful effects to the public caused by the use of an invalid patent, sce Bennett, The Amortcan Patent Systenc 107 (1943); Brown, Development in the Patent Law as Affected by Adjudication, 22 J. PAT. OFF. Soc'y 587 (1940); Evans, Sone Stray Thoughts of a Federal Judge on our Patent System and its Operation, $27 \mathrm{~J}$. PAT. OFF. Soc'y 293, 308 (1945).

39. This correction may consist of mere verbal reproof. On the other hand, appellate tribunals may use the direct method of expunging superfous findings of validity from the record. See Wabash Corp. v. Ross Electric Corp., 187 F.2d 577, 587 (2d Cir. 1951) (partially concurring and partially dissenting opinion). And they may reform decrees to include holdings of invalidity, whenever such reform is warranted. 


\section{THE PRIVILEGE AGAINST SELF-INCRIMINATION: THE DOCTRINE OF WAIVER *}

THE effectiveness of the privilege against self-incrimination ${ }^{1}$ is lessened by several judicial rules regulating its application. The privilege can be involked only by claiming it specifically. ${ }^{2}$ Even when claimed the privilege is unavailable if the court thinks that no possible answer to a question would tend to incriminate. ${ }^{3}$ Moreover, a witness may be compelled to answer clearly incriminating questions if a statute guarantees immunity from prosecution." Finally, the privilege may be lost by "constructive waiver" inferred from answers to prior questions.

As evolved in state courts, the constructive waiver doctrine has been applied with varying degrees of severity. Some courts have held that where a witness enters upon the exposition of a particular transaction, even though he has not yet incriminated himself, he must go on and make a full disclosure. The more

*Rogers v. United States, 340 U.S. 367 (1951), rehcaring denicd 341 U.S. 912 (1951).

1. "No person ... . shall be compelled in any criminal case to be a witness against himself." U.S. CoNST. Asrend. V. See generally Counselman v. Hitcheock, 142 U.S. 547 (1892) ; Corwin, The Supreme Contr's Construction of the Self-Incrimairation Clause, 29 Mrcm. L. REv. 1, 191 (1930), which details the way in which 100 years of interpretation have overcome the limitations of the phrase "criminal case" so as to protect witnesses in grand jury and legislative investigations, civil trials, and practically all other proceedings.

2. The usual phrase is that the privilege must be "in some manner fairly brought to the attention of the tribunal. . .." United States ex rel. Vajtauer v. Commissioner of Immigration, 273 U.S. 103, 113 (1927).

3. Mason v. United States, 244 U.S. 362 (1917). See also 19 Mirms. I. Rev. 426 (1935).

The guiding principle was first stated by Chief Justice Marshall:

"[T] he court ought never to compel a vitness to give an answer which discloses a fact that would form a necessary and essential part of a crime which is punishable by the laws." In re Willie, 25 Fed. Cas. 38, 40, No. 14, 692e (C.C.D. Va 1807).

See also United States v. Cusson, 132 F.2d 413, 414 (2d. Cir. 1942):

"It is obvious that no general principle can be laid down; the question is always whether the danger to be apprehended from an answer is near enough to be real, or whether it is too remote to be substantial."

On the purpose and operation of the privilege, see Reg. v. Boyes, 1 B. \& S. 311 (1861); Comment, 49 Y AlE L.J. 1059 (19\$0); Shientag, The Right to Refuse to Auster, N. X. Times MFag., April 22, 1951, p. 20.

4. Brown v. Walker, 161 U.S. 591 (1896) (the first decision to uphold an immunity statute, on the ground that it afforded all the protection of the privilege). But cf. Counselman v. Hitchcock, 142 U.S. 547 (1S92) (striling down the first immunity statute as not affording a protection co-extensive with the privilege). For general diseussion and history, see United States v. Mfonia, 317 U.S. 424 (1942); \& Wigsone, Evirence $\$ 2231$ (3d ed. 1940) (hereafter cited WrGurone).

5. Foster v. Pierce, 65 Mlass. (11 Cush.) 437 (1853); State v. Nichols, 29 Minn. 357 (1882); Town of Norfolk v. Gaylord, 28 Conn. 309 (1859). Cf. Ginn v. Commonwealth, $15 \mathrm{Ky}$. (5 Litt) 300 (1824). 
general rule is that when a witness voluntarily admits some connection with a crime, he must then tell the whole story. ${ }^{6}$ A few courts find waiver only after a witness has confessed to all the formal elements of a crime. ${ }^{7}$

In Rogers $v$. United States ${ }^{8}$ the Supreme Court for the first time used constructive waiver to deny a witness protection of the privilege. Jane Roger's was one of several persons cited for contempt in the course of a grand jury investigation of Communist Party activities in Colorado. ${ }^{0}$ After admitting that she had been treasurer of the Party, she refused to disclose the name of the person to whom she had turned over records formerly in her keeping. ${ }^{10}$ She

6. State v. Foster, 23 N.H. 348 (1851) ; People v. Freshour, 55 Cal. 375 (1880). Scc also Commonwealth v. Price, 76 Mass. (10 Gray) 472 (1858). Peoplc v. Freshour conttains a typical statement of the transaction theory:

"If a witness discloses a part of a transaction with which he was criminally contcerned, without claiming his privilege, he must disclose the whole." Id. at 377.

7. United States v. St. Pierre, 132 F.2d 837 (2d. Cir. 1942) ; Eggers v. Fos, 177 Ill. 185 (1898). Cf. Foster v. People, 18 Mich. 266 (1869), which is most frequently citcd it support of the looser rule (see note 6 supra), but whose holding on the facts is more in line with the St. Pierre rule.

8. 340 U.S. 367 (1951), rehearing denied 341 U.S. 912 (1951). See also Rogers v. United States, 179 F.2d 559 (10th Cir. 1950). The Rogers case grew out of the same grand jury investigation as, and was argued along with, Blau v. United States, 340 U.S. 159 (1950).

Arndstein v. McCarthy, 254 U.S. 71 and 379 (1920), previously the controlling Supreme Court decision, held that the defendant, who claimed his privilege in the course of a bankruptcy examination subsequent to having filed an involuntary bankruptcy, had not waived his privilege by virtue of the original filing. For further litigation, see MeCarthy v. Arndstein, 262 U.S. 355 (1923); McCarthy v. Arndstein, 266 U.S. 34 (1924). Sce also note 6 of Mr. Justice Black's dissent in the principal case, 340 U.S. 367, 378-379, criticizing the majority's reinterpretation of the Arndstein case. The Arndstcin decisions relied upon the broad interpretation of the privilege arrived at in the leading case of Counselman v. Hitchcock, 142 U.S. 547 (1892), supra note 4; and on the even broader English rule first enunciated in Reg. v. Garbett, 2 Car. \& K. 474, 175 Eng. Rep. 196 (1847), infra note 24. For adverse comment on the Arndstein holding, sce 8 Wiguowe $\S 2276$ n. 5 .

9. It is noteworthy that the court of appeals, while affirming Mrs. Rogers' conviction, pointedly criticized both the tactics of the Special United States Attorney in charge and the trial proceedings. Rogers v. United States, 179 F.2d 559, 561 (10th Cir. 1950).

10. The reason for her refusal was initially and naively expressed as follows:

"I 'I don't feel that I should subject a person or persons to the same thing that I'm going through." Rogers v. United States, 340 U.S. 367, 369 n.1 (1951).

The Court perhaps considered this to be an independent ground of its decision.

While there are numerous decisions to the effect that the privilege is for personal protection only, United States v. Herron, 28 F.2d 122 (N.D. Cal. 1928), citing E.r part' Irvine, 74 Fed. 954 (C.C.S.D. Ohio 1896), is some authority that a witness can claim the privilege "irrespective of his motive" Id. at 123. But sce People v. Schultz, 380 Ill. 539, 41 N.E.2d 754 (1942) (refusal to answer solely to protect third party not allowed); United States v. St. Pierre, 132 F.2d 837 (2d Cir. 1942) (see note 14 infra); and Hale v. Henkel, 201 U.S. 43 (1906) (early antitrust case: flat holding against this use of the privilege). 
argued that an answer to the question could incriminate her under the Smith Act, which makes it a crime to be a member of a group which one knows advocates the forceful overthrow of the government.11 The Supreme Court said that since no answer to the question to which Mrs. Rogers refused to respund could further incriminate her after she had admitted party membership, slue could not invoke the privilege. ${ }^{12}$

The reasoning in Rogers suggests that the Court sanctioned only the most limited type of waiver-that arising after full voluntary incrimination. But the facts of the case indicate a rule of broader application. The Smith Act does not make a crime of mere membership and activity in a group advocating furcuful overthrow of the government; it also requires that the accused lnuw of this purpose. ${ }^{13}$ Mrs. Rogers had not yet admitted such knowledge, and it is cunceivable that the person who replaced her as treasurer could help a prusecutur to establish this knowledge.

In line with prior cases, Rogers makes it clear that, once there has been sime disclosure, a person can be forced to give evidentiary leads to help convict himself. ${ }^{14}$ Even if Mrs. Rogers had already confessed all the elements necessary for conviction under the Smith Act, further details could be of ail in' a

While Mirs. Rogers did not at first refuse to answer because of her privilege, neither was there any evidence that the original finding of contemit was bascd on the doctrine of waiver. See full transcript appended to principal case, 340 [5.S. 367, 331-38? 119511 .

11. 18 U.S.C. $\$ 2385$ (Supp. 1951). In Blau v. United States, 340 U.S. 159 (19j0) the Court held that answers to questions as to membership in the Cummunist Party were privileged as tending to incriminate under the Smith Act. Prior to the Blun decision, this was an open question. See Alexander v. United States, 181 F.2d 480 (9th Cir. 1950) (after much judicial difficulty, a divided court en bane held refusal to answer justified).

12. Rogers v. United States, 340 U.S. 367. $374-5$ (1951).

13 The pertinent phrase of 18 U.S.C. $\$ 2385$ (Supp. 1951) reads:

"or becomes or is a member of, or afiliates with, any" such socicty, group, or assembly of persons, lnowing the purposes thereof. . .."

See Dennis v. United States, 341 U.S. $494,499-500$ (1951), for indieation that intent is an essential element of proof under the Smith Act.

14. The case most in point, prior to the Rogers decision, was Unitcd Statss v. St. Pierre, 132 F.2d 837 (2d Cir. 1942), apfoul dismissod as mmot, 319 U.S. 41 111421; noted, 56 HARv. L. REv. 832 (1943). The grand jury witness in this case testified to having committed the crime of embezzlement; he subsequently refused to divulge the name of the person to whom he had given the embezzled money. Judge Learne.l Hond sustained the contempt conviction on the doctrine of waiver, holding that the vitness had disclosed all the elements of the crime of embezzlement. Judge Jerome Franl: in an informed and helpful dissent, maintained that the government's case was "incomplete" without disclosure of the fact demanded. (See Rogers v. United States, 340 U.S. 367, 375 n. 19 (1951), for the majority's surprising intimation of a possible agrcement with Judge Frank's point here)

The question of "evidentiary leads" is all-important, since the point is not to indiet but to convict. After all, the government's whole case might hinge upon a "detail," and if such a "detail" is not privileged, the Constitutional provision would seem very muth on the wane. 
successful prosecution. The government might not be willing to go to court on the basis of a bare admission of formal elements.

The Supreme Court apparently equates waiver at a grand jury hearing with waiver at a trial. But the great majority of early waiver cases were adversary proceedings. ${ }^{15}$ And the usual justification of the doctrine is that in its absence a witness for one side would be able, under questioning of friendly counsel, to present a distorted picture of the facts, while escaping the corrective of a vigorous cross-examination. ${ }^{16}$ Instead of ruling out such one-sided testimony altogether, ${ }^{17}$ courts preferred to use waiver to protect the rights of parties. They required disclosure of "details" to place the testimony in a balanced perspective, and to ensure a fair trial. ${ }^{18}$ The right of the witness was sacrificed to the right of the adverse party.

This doctrine, along with its rationale, has been applied uncritically to inquisitorial proceedings. ${ }^{19}$ The desirability of this extension is questionable. Although grand jury or legislative hearings may result in accusations against individuals, there are no "adverse" parties whose rights to cross-examination might be jeopardized by partial disclosure. ${ }^{20}$ And in an inquisitorial proceeding the witness is entirely in the hands of counsel for the state who may subject the witness to questioning equivalent to a searching cross-examination. In addition, the balance of interests here is between the state's right to information

15. See e.g., Foster v. People, 18 Mich. 266 (1869) which is among the most frequently cited authorities. For early leading cases see 8 WIGMore $\$ 2276$ n. 1; 147 A.L.R. 255-82; the Solicitor General's brief in the principle case, particularly at p. 26; and notes 5,6, aut 7 supra. The doctrine of waiver seems to have been developed in the carly state cases, which deal mainiy with problems arising upon cross-examination.

16. A typical rationale of the doctrine of waiver is that in Commonwealth va Price, 76 Mass. (10 Gray) 472, 476 (1858):

"If he [the witness, an accomplice] could be allowed so to do [to claim his privilege on cross], injustice might be done to the defendant, either by the kceping back of testimony which would tend directly to his acquittal, or which would so discredit the witness as to induce the jury wholly to disregard his previous testimony."

17. Historically, this was an early technique used both here and in England. See Pinkard v. State, 30 Ga. 757 (1860); Dandridge v. Corden, 3 Car. \& P. 11, 172 Eng. Rep. 300 (1827). For an early rationale of the attitude against waiver, see Mayo v. Mayo, 119 Mass. 290 (1876), where it was held that the judge might instruct as to the privilege at a late hour-

"otherwise the witness might be entrapped into a position where his privilege as a witness would be entirely defeated by his ignorance, and he would be obliged fully to incriminate himself." Id. at 292.

See notes 23 and 24 infra.

18. Cf. Commonwealth v. Price, supra note 16.

19. See, e.g., Ex parte Adams, 76 Tex. Crim. Rep. 277, 174 S.W. 1044 (1915), citing Ex Parte Park, 37 Tex. Crim. Rep. 590, 40 S.W. 300 (1897), both non-adversary proceedings, where the same reasons for the holding are given which had been offercd in adversary proceedings for 75 years.

20. See Frank, J., dissenting, in United States v. St. Pierre, 132 F.2d 837, 845 (2d Cir. 1942). See also note 22 infra. 
and the witness' right not to incriminate himself. Sacrifice of the witness' right to that of the state attacks the underlying purpose of the privilege-to prevent the state from forcing incrimination by abuse of the inquisiturial method. ${ }^{21}$ It is one thing to limit the privilege in order to safeguard adversaries in a trial $;^{22}$ it is quite another to weaken its protection against the very dangers which first made it necessary.

Application of the waiver doctrine to inquisitorial proceedings creates a dilemma for witnesses which endangers their rights and at the same time may hamper the truth-seeking function of these hearings. Answering questiuns causes loss of the privilege; refusal to answer may bring on contempt sentences. ${ }^{23}$ Since the average witness will surely be uncertain when and when not to answer, he will probably try to say as little as possible. He will scrutinize each question for hidden and remote dangers. The number of contempt proceedings may increase, but by thus making witnesses wary, the state will simply get less information.

Assuming the value of protection against self-incrimination, the best solution for the problem created by waiver in inquisitorial proceedings would be the English rule that a witness may claim his privilege at any stage of the inquiry:-2 But the English rule is unlikely to be accepted in this country because of the

21. On the history of the privilege, see note 3 stpra; $\$$ Wrgasone $\$ 2250$; and Corwin, supra note 1 . Briefly put, the privilege developed as both a popular and judicial reaction against the $c x$ officio oath of criminal equity (which had a religious bacliground), and particularly the procedures of the infamous Star Chamber.

22. This Note makes no attempt to discuss the doctrine of waiver as anplicl to adversary proceedings; the argument here is simply that the same considerations do not apply to inquisitorial hearings. See United States v. St. Pierre, 132 F.2d \$37, \$40 (2d. Cir. 1942) and Judge Frank, dissenting, at 845.

23. See Black, J., dissenting, in Rogers v. United States, 340 U.S. 367, 375-81 (1951). For another discussion of the witness' dilemma, see Estes v. Potter, 183 F.24 865 , 868 (5th Cir. 1950).

24. Reg. v. Garbett, 2 Car. \& K. 474, 175 Eng. Rep. 196 (1847). This very interesting case concerned a witness in a forgery trial, an attorney, who was forced by the judge on grounds of waiver, to give a self-incriminating answer: it was held that the evidence so gained could not later be used against him. The decision reversed earlier prevelent, and stopped once and for all the growth of an American style doctrine of waiver. For modern cases on the English rule, see 13 Halsbury, Laws of Exglasid $730-3$ (2d ed. 1934).

For accasional American applications of the English rule, see Chesanealie Club v. State, 63 MId. 416 (1885); State v. Allen, 183 M1d. 603, 39 A.2d $\$ 20$ (1944); and critical comment in 10 Mp. L. Rev. 158 (1949). See also Perple v. Giallarenzi, 150 Mlire. 11, 268 N.Y. Supp. 488 (Sup. Ct. 1934). For an early view favoring the English rule, see People v. Mead, 50 Mich. 228, 15 N.W. 95 (1883) ; and a critical discussion of Judge Cooley's ideas in 8 WIGASORE 449.

For an on-the-point discussion of the modern waiver doctrine, see Heyler, Privileyc against Self-Intrimination in Federal Grand Jury Procedings, 38 C.uLr. L. REv. 924, 930-1 (1950). 